\title{
Submarine Cables as an Object of Legal Regulation under International Law
}

\author{
Daria Shvets*
}

\begin{abstract}
Submarine cables laid on the bottom of the ocean, connecting continents and nations worldwide, have specific and extraordinary legal nature. The current legal regime of submarine cables mostly formed by the law of the sea and domestic law of states depends on several key characteristics influencing the formation and development of such regime. First, submarine cables represent the plurality of interests of numerous stakeholders: public, private and those of a mixed nature. They combine a variety of legal relations concerning submarine cables taking place in different maritime zones in accordance with the law of the sea. Second, they form critical infrastructure being the backbone for modern Internet and telecommunications. Currently most of all international data traffic goes through submarine fibre optic cables. Third, submarine cables can be considered as an object of a global public interest serving needs of the whole international community. By providing the analysis of key distinguishing characteristics of submarine cables this article hopes to bring better clarity on the nature of submarine cables as an object of legal regulation under international law and attract legal scholars' attention to this important but sometimes underestimated topic of international law.
\end{abstract}

Keywords: Submarine cables-public international law -global public interest-stakeholders - law of the sea telecommunications.

\section{(A) INTERESTS OF DIFFERENT STAKEHOLDERS IN SUBMARINE CABLES}

Submarine cables appear to be an infrastructure accumulating interests of various stakeholders. It might be characterized as multi-faceted and diverse collection of various goals set by such stakeholders that become possible to be achieved due to submarine cables network. Submarine cables not only demonstrate the plurality of public relations taking place around them but also that the nature of this object of regulation is diversified.

Principal stakeholders interested in submarine cables usage are states; business sector represented by content providers, telecommunications companies and IT giants; and individuals as final consumers. The value that submarine cables bring is addressed to all of them but each stakeholder finds its own benefit in using cables as it will be addressed further.

\section{(1)Interests of States}

Two different groups of states' interests in submarine cables can be distinguished: interests when laying a submarine cable (primary interests); and interests resulting from having a submarine cable in a maritime zone of such state (subsequent interests).

Regarding the primary interests, all states members of the United Nations Convention on the Law of the $\mathrm{Sea}^{1}$ (hereinafter UNCLOS), the main international agreement addressing submarine cables, are granted the right to lay cables in different maritime zones. ${ }^{2}$ The same applies to non-parties of the UNCLOS by virtue of customary international law. The UNCLOS does not divide states by

Adjunct Professor, Universitat Pompeu Fabra. Email: daria.shvets@upf.edu.

1 United Nations Convention on the Law of the Sea (adopted 10 December 1982, entered into force 16 November 1994), 1833 UNTS 397.

2 Ibid, Article 58, paragraph 1; Article 79, paragraph 1; Article 87, paragraph 1 (c); Article 112, paragraph 1. 
consideration of coastal or land-locked state or by any other criteria making all states equal in this right. Thus, states are entitled to lay submarine cables in other states' maritime zones according to international law.

As for subsequent interests, states perform on the other side being parties welcoming cables in their maritime zones. In particular, states are interested in regulating cable related activities given that the project is implemented in maritime zones under a state's jurisdiction. Therefore, coastal states regulate cable installation in their domestic legal orders ${ }^{3}$ wishing their interests to be respected. From this perspective, states perform controlling functions and ensure a competition between providers that is especially relevant for developing states. ${ }^{4}$ When laid in states' maritime zones they ensure their economic, environmental and security interests. ${ }^{5}$

Submarine cables connect states with the external world contributing into their economic development. Even remote territories or islands may stay connected to take part in world policy by electronic means that appeared to be even more relevant in the course of covid-19 pandemic. Australia and New Zealand, for instance, significantly rely on submarine cables transmitting over $99 \%$ of all their international communications. ${ }^{6}$ The Australian navy, for instance, announced "three-ocean" strategy protecting submarine cables from terrorist attacks ${ }^{7}$, understanding the crucial impact from cables for geographically remote Australia highlighting that cables should be free from all kinds of threats.

Another dimension from which states and the international community might be interested in submarine cables is environmental dimension. It becomes relevant not only for remote territories but for the common wealth of the whole world. Video conferences, video calls and other means of telecommunications may contribute to the protection of the environment eliminating the necessity to transport people and resources to a certain destination and as a result reduce $\mathrm{CO} 2$ emissions. For instance, a 2-day video conference between New York and Stockholm would produce 5,7 kg of CO2 due to the operation of submarine cables while CO2 emissions from aircraft used for bringing only 2 participants of the conference would count to 1,920 kilograms. ${ }^{8}$ That might be especially relevant for states in building their agenda on mitigation of climate change and obligations taken before international community in relation to it.

One more factor for states to seriously consider submarine cables is that they rely on cables for security interests. Some cables are laid for military purposes and ensure national security. Historically submarine cables were used by governments for various military operations such as bilateral

${ }^{3}$ As an example, see analysis of detailed legal regime established by the Russian Federation on submarine cables in D. Shvets, 'The Experience of the Russian Federation in the Legal Regulation of Submarine Cables', Central and Eastern European Legal Studies, 1, 2017, 163-199.

4 International Telecommunications Union, Access to Submarine Cables: Guidelines, Harmonization of ICT Policies in Sub-Saharan Africa HIPSSA, Geneva, 2013, at 1, accessed 18October 2021.

5 For instance, Spain concerns national maritime security as the action of the state aimed at protecting national interests related to, inter alia, submarine cables. See B. Navarro, 'A Comprehensive New Approach: The National Maritime Security Strategy', Spain and the Law of the Sea: 20 years under LOSC, Spanish Yearbook of International Law(2017), 21, 225-238,at 231[doi: 10.17103/sybil.21.13].

6 Department of Broadband, Communications and the Digital economy, Submarine Cable Information Sharing Project: Legislative Practices and Points of Contact, Australia, 2012, at3, accessed 18October 2021.

7 P. Khanna, Connectography: mapping the future of global civilization (Random House,New York, 2016 ), at 126.

8 D. Burnett, 'Impacts on international submarine cables by coastline state encroachment based in natural resources and environment', in L. Martin, C. Salondis, C. Hioureas, Natural Resources and The Law of the Sea, Exploration, Allocation, Exploitation of Natural Resources in Areas Under National Jurisdiction and Beyond (Juris, New York, 2017), $147-184$, at 162 . 
communications, acoustic monitoring, and telecommunications. ${ }^{9}$ However, some cables continue performing their initial functions, such as facilitating financial transactions, supporting surveillance systems, collecting intelligence, listening through hydrophones, et cetera. ${ }^{10}$

\section{(2)Interests of Business Sector}

Not only states but large business players such as banks, stock exchanges, airlines, and maritime industry also depend on submarine cables forasmuch as they ensure daily communications, transactions, and communications of business. Multinational corporations, telecom carriers, mobile operators, and content providers depend on submarine cables for the prosperity of their business. In particular, the Society for Worldwide Interbank Financial Telecommunications (SWIFT) daily transmits 15 million messages to more than 8300 banking organizations, securities institutions, and corporate customers in more than 200 countries or entities. ${ }^{11}$ The global significance for domestic economies and communications is reported as increasing every year. ${ }^{12} \mathrm{By}$ way of example, the company Amazon uses submarine telecommunications cables for improving the speed and quality of its web services, as well as Japanese Softbank relies on submarine cables for "building and optimizing its network infrastructure to support rapidly increasing traffic demand and its customers". ${ }^{13}$ Wellknown content providers Netflix and Spotify also rely on submarine cables to transfer their data to customers. ${ }^{14}$ Apart from major players of the market, middle class and small business in every state also depend on submarine cables. Travel agencies, supermarkets, restaurants, or local stores might serve as examples.

One more dimension of submarine cables' impact for business is shipping costs reduction. In combination with the development of 3D printing technologies, it might not be necessary to transport goods by sea or carry parcels by air from one part of the world to another. Submarine cables by transferring necessary information, may contribute into in-demand printing of objects at a place without the need of transportation. The cable industry is nowadays looking for faster and better development of 3D printing technologies for faster growth of this potential sector of cooperation. ${ }^{15}$

\section{(3)Interests of Individuals}

Submarine cables are laid and further operated in the framework of private law contracts between two legal entities basically acting as seller and purchaser of a cable system and are parts of business projects. At the same time, submarine cables also serve for needs of final costumers such as individuals providing people with Internet, the possibility to make calls, send messages, and have access to data transmitted by cables.

Although legally cables are laid in favor of a contracting party under a contract, this fact does not change submarine cables' nature. In a legal sense, submarine cables are considered as a property of

9 D. Burnett, T. Davenport, R. Beckman, Submarine cables: The Handbook of Law and Policy (Martinus Nijhoff, Leiden, 2014), at 339.

10 B. Clark, 'Undersea Cables and the Future of Submarine Competition', Bulletin of the Atomic Scientists, 72, Issue 4, 2016, 234-237, at 234[doi: 10.1080/00963402.2016.1195636].

11 Supra n. 8, at1.

12 Submarine Telecoms Forum, Submarine cable almanac, issue 24, 2017, at 2, accessed 18October 2021.

13 See website of Softbank, accessed18October 2021.

14 B. Morris,'Submarine cables: a deep dive into underwater connectivity', Tata Communications New World Blog, 2015, 1-4, at. 1, accessed 18October 2021.

15 Supra n. 7, at 162. 
the owner who is free to act with cables upon its will. However, the last consumer of cables as a product is general audience and individuals. Eventually they are placed for public purposes.

Submarine cables make connections global and allow transmitting data from one part of the world to another. Today anyone could have business with anyone by working remotely on the Internet. Mailboxes and professional social networks require daily access to the global network of submarine cables. Such cooperation between users around the world eliminates state borders, customs formalities, and distances to make people connected.

One more perspective from which individuals are interested in submarine cables is the right to online education. There are numerous online resources and programs available with Internet access nowadays that becomes especially relevant for remote and northern territories whose only way to external world is Internet. ${ }^{16}$ The same applies to health care and telemedicine available online. ${ }^{17}$

\section{(B) SUBMARINE CABLES AS TELECOMMUNICATIONS INFRASTRUCTURE}

Infrastructure is primarily a tool helping a particular activity to be performed and developed further. In the present case submarine cables could be considered as a critical infrastructure for transmitting telecommunications as it is discussed below.

\section{(1)Definition of Submarine Cables as an Infrastructure}

Taking into consideration interests of different stakeholders in submarine cables operation and consequently, cables' public-private nature, they may be considered as infrastructure. The infrastructure can be defined as "the basic physical and organizational structure needed for the operation of a society or enterprise or the supporting structure/base/foundation for a system or organization." ${ }^{18}$ In the case of submarine cables, it is not local and not always regional infrastructure but the infrastructure that often serves for an international community. Therefore, the definition of "global information infrastructure" may also be considered as applicable to submarine cables: "proposed telecommunications and information technology networks as a governmental and nongovernmental, worldwide infrastructure. Its objective is dissemination of information and remote collaboration spurring faster and greater economic growth". ${ }^{19}$ Thus, submarine cables as a global information infrastructure have several important elements to examine.

\section{(2)Elements of Submarine Cables as an Infrastructure}

The development of succesful infrastructure is becoming a prerequisite for successful country's development, especially for small countries allowing them to join the international market either through promotion of tourism, advertising of favourable business environment, or providing

16 D. Shvets, 'The Legal Regime Governing Submarine Telecommunications Cables in the Arctic: Present State and Challenges', in M.Salminen, G.Zojer, K.Hossain, Digitalisation and Human Security (Palgrave Macmillan, Switzerland, 2020), 175-203[doi: 10.1007/978-3-030-48070-7_7].

17 S. von Schorlemer,'Telecommunications, International Regulation', MPEPIL, 2009, 16, at 1, accessed 18 October 2021.

18 C. Turner and D. Johnson, Global infrastructure networks (Edward Elgar Publishing Limited, Northampton, 2017), at 1 .

19 B. Garner (ed.), Black's Law Dictionary, $7^{\text {th }}$ edition (West Publishing Co., St. Paul, Minn., 1979). 
investment opportunities. ${ }^{20}$ Submarine cable in service means physical elements to be installed on the seabed and onshore. Such physical elements include cables themselves, landing stations and repeaters among other things under the property of public entities, private companies, or companies of a mixed legal nature as it was discussed above. At the same time, cables are laid in various maritime zones attributed exclusively to states (except for the high seas and international seabed area, maritime zones not falling under any state's jurisdiction), and no private actor can claim a maritime zone to be owned by it. Thus, an analysis of submarine cables as an infrastructure contributes to understanding of cables as an object of legal regulation.

\section{(i) Property}

Successfully developed material infrastructure powers the existence of services enabled by it. The history even knows examples of exclusive use of the Internet powered by submarine cables when all other means of communications including regular mail or face to face communication were blocked for political reasons. ${ }^{21}$ In the present time, governments are able to provide services online, respond to queries and better communicate with citizens due to well-working tangible submarine cables infrastructure. Thus, the ownership and proper maintenance of the infrastructure matter.

Submarine cables as an infrastructure may belong to different kind of stakeholders. A major part of all submarine cables constitutes a private property of legal entities or consortium of legal entities aimed at providing telecommunications services. ${ }^{22}$ Sometimes cables are owned by a solo proprietor (for instance, cable Junior is owned by tech giant Google individually connecting two locations in Brazil with more and more investments being made by this company in other cables). ${ }^{23}$ Sometimes the infrastructure may be leased. For instance, a time on a submarine cable is leased without the necessity to own it. ${ }^{24}$ The same applies to cable stations facilities onshore. They can be leased from a coastal state, or a company headquartered in such state. ${ }^{25}$ Another form of property is when a cable is in the public domain. Although this situation is not common in the cable industry some examples may be found in practice. One would be a cable Saba, Statia Cable System (SSCS) owned by the Government of Netherlands. ${ }^{26}$ Forms of submarine cables possession may vary that one more time underlines their hybrid and complex legal regime.

\section{(ii) Location}

Despite different type of ownership in the area of submarine cables, rules andmaritime zones dividing the ocean established by the UNCLOSremain the same. Thus, submarine cables as an infrastructure are laid in maritime zones under the sovereignty of coastal states (territorial sea and archipelagic

20 L. Main, 'The global information infrastructure: empowerment or imperialism?', Third World Quarterly, 22, No 1, 2001,83-97, at 95[doi: 10.1080/01436590020022592].

21 During the 1995 conflict in the Balkans the external server helped people separated by the conflict to communicate. See supra n. 19 , at 84 .

22 For instance, a submarine cable Circle North connecting Netherlands with England is owned by two companies: euNetworks headquartered in the United Kingdom (see more information at the company's website, accessed 18 October 2021) and VTLWaveNet, also a privately held company (see more information at the company's website, accessed 18 October 2021). Therefore, a cable constitutes a joint private property of these two companies.

23 Telegeography, Submarine Cable Map, accessed 18 October 2021.

24 R. Miller, 'Google's latest undersea cable project will connect Japan to Australia', TechCrunch, 2018, 1-2, at 1 , accessed 18 October 2021.

25 S. Esselaar, A. Gillwald, E. Sutherland,'The regulation of undersea cables and landing stations', International Development Research Centre, 1-16, at 3, accessed 18 October 2021.

26 Supra n. 22. 
waters), maritime spaces not under the sovereignty of coastal states but where they have rights to exercise certain jurisdiction (contiguous zone, exclusive economic zone, and continental shelf) and maritime areas not subject to the jurisdiction of coastal states (high seas and international seabed area).

Essential infrastructure providing society with public goods deserve well-developed legislation specifying their certain status. It becomes even more relevant when the infrastructure is global and serves for the needs of the international community. The infrastructure helps states and communities to prosper, maintain and develop economic wellbeing, and stay connected to the rest of the world. This is the reason why states aim to develop and maintain its modern infrastructure and specify it as one of top prioroties of national development strategy. ${ }^{27}$ In other cases states at least intend to have a minimum level of regulation and enact domestic acts implementing their UNCLOS obligations. However, there are still cases of underdeveloped legal regime of submarine cables under international law. That means not all states put enough efforts to develop a comprehensive legal regime regulating submarine cables in maritime zones under their jurisdiction so that it causes practical implications and difficulties for cable projects in practice.

\section{(C) SUBMARINE CABLES AS A MATTER OF GLOBAL PUBLIC INTEREST}

Legal norms of public interest are norms addressed to regulate most important matters of an international community since they accumulate different interests of various groups. Together they are based on common values recognized by states, international organizations, civil society, and all other stakeholders on international arena admitting the necessity of existence of such interests. ${ }^{28}$ In the light of this concept submarine cables can be considered as an issue comprising global public interest.

\section{(1)Definition of Global Public Interest}

The modern international law does not provide with the definition for the term of a "global public interest" but there is a shared vision that global public interest is expected to be for the benefit of all. There are, however, various definitions of a "public interest" in academic papers. In the legal doctrine, it is defined, for instance, as "an interest of society as a whole, i.e. an interest that goes beyond the interest of the individual or of mere factions. ${ }^{29}$ Another definition of authoritative Black's Law Dictionary suggests that a public interest is: "(1) The general welfare of the public that warrants recognition and protection; and (2) Something in which the public as a whole has a stake; especially an interest that justifies government regulation". ${ }^{30}$ Alternative definition to be found in Barron's Dictionary refers to public interest as "that which is best for society as a whole", but then adds it is "a subjective determination by an individual such as a judge or governor, or a group such as a [...]

27 President of the Russian Federation,Decree of n. 645 'On the Strategy for the Development of the Arctic Zone of the Russian Federation and Ensuring National Security for the Period until 2035', accessed 18 October 2021.

28 Supra N. 17, at 6.

29 A. Bělohlávek, 'Public Policy and Public Interest in International Law and EU Law',in Czech Yearbook of International Law, A. Belohlavek, N. Rozehnalova (eds.) (JurisPublishing, Inc.,Huntington, New York,2012), 117-149, at 120 .

30 Supra n. 18. 
legislature of what is for the general good of all people". ${ }^{31}$ In the abundance of definitions, there is, however, still no agreement between scholars what should be considered as a public interest. ${ }^{32}$ The traditional concept arguing that "public" means pertaining to a state, the state-oriented, or equalling to the interest of a state, does not apply in the case of submarine cables. The public interest, especially when it is a global public interest does not mean the sum of individual interests of states but constitutes the interest of a different nature. ${ }^{33}$ States within the international legal order are considered as sovereign and equal subjects constructing the horizontal and decentralized system. ${ }^{34}$ However, as opposed to this traditional concept the new notion of a public interest has emerged stating that public interest does not mean an interest of a state but the interest of an international community as a new object of regulation by the international legal order. ${ }^{35}$ That said, states do not have their own interests but rather have one common interest together with other actors. Since the complex system of current international law involves interests of many actors and constitutes more than particular individual interest, the global public interest should be considered as an interest of the international community.

\section{(2)Global Public Interest as an Interest of the International Community}

Global public interest contains the interest of an international community meaning that in the modern world states are not the only stakeholders. They coexist together in a manner of interdependence and cooperation with other international law actors. Such actors, for instance, international governmental organizations, international non-governmental organizations, and individuals should successfully integrate to the international community. Therefore, the current international law represents the variety of actors with complex relations between themselves. At the same time, it remains reluctant and conservative regarding the involvement of non-traditional institutions to the law-making process arguing that states "have not been challenged towards the protection of community interests". 36

Despite the conservativeness of international law, the central element to be considered is the existence of collective interests, matters constituting a concern to all stakeholdersin international law. These interests are different from the interests of any of the stakeholder taken individually since such interests identify a shared value that all stakeholders recognize as the one that needs common protection, a collective action under international law. Global public interest consisting of collective interests that are not the sum of individual interests but concerns of the international community as a whole constitutes general interest. This general interest should be regulated by rules and institutions of international law and deserves legal protection reflecting social interests. ${ }^{37}$ Judge Simma of the

31 S. Gifis, Law Dictionary, $4^{\text {th }}$ ed. (Barron's Educational Services,New York, 1996).

32 R. Huesa, 'La protección del interés público global: una nueva dimensión para las normas y obligaciones internacionales', in N. Bouza, C. García, Á. J. Rodrígo, Coordinador: P. Pareja, La gobernanza del interés público global(XXV Jornadas de la Asociación Española de Profesores de Derecho Internacional y Relaciones Internacionales, 2015), 253-286, at 255.; A.Rodrigo, 'Más allá del derecho internacional:el derecho internacional público', in R. MéndezSilva, Derecho internacional, primera edición, (UNAM, Instituto de Investigaciones juridicas,México, 2019),67-98, at 77. 355 .

33 O. Casanovas, A. Rodrigo, Compendio de Derecho Internacional Público, sexta edición (Tecnos,Madrid, 2017), at

34 P. Reuter, Droit international public, $7^{\mathrm{a}}$ ed. (Presses Universitaires de France,Paris, 1993), at 22.

35 E. Riedel, 'International Environmental Law. A Law to Serve the Public Interest? An Analysis of the Scope of the Binding Effect of Basic Principles (Public Interest Norms)', in J. Delbrück (ed.), Proceedings of an International Symposium of the Kiel Walther-Schücking-Institute of International Law (Duncker \& Humblot, Berlin, 1997 ), at 97.

36 S. Villalpando, 'The Legal Dimension of the International Community: How Community Interests are Protected in International Law', European Journal of International Law, 21, 2010, 387-419, at 410 [doi:10.1093/ejil/chq038].

37 Supran. 31, at 155-156. 
International Court of Justice once noted "[a] rising awareness of the common interest of the international community, a community that comprises not only states, but in the last instance all human beings, has begun to change the nature of international law profoundly." 38

There are three elements to be covered by the notion of a public interest. First, objects of a public interest re in service to meet the needs of international community in general. Second, their origin is in interdependence. Third, they are characterized by their lack of reciprocity. ${ }^{39}$ Thus, interests of international community should be protected by the international legal order and submarine cables deserve the status of the interest of an international community.

\section{(3) Recognition of Submarine Cables as a Matter of Global Public Interest}

There is no definitively established list of areas of international law to be considered as a global public interest and any area might be attributed such status should there be a reason for it. Activities rising around submarine cable might be examined as one of such areas constituting the global public interest. Not only they constitute an object of a public interest but appear to be a matter of global public interest in the meaning that many stakeholders on different territories equally recognize the value of services brought by submarine cables. There are two elements connected to the interest. First is global, meaning that submarine cables are not an object causing concern only in a particular territory or in a particular state. Submarine cables are laid worldwide and ensure stable telecommunications in various territories. Second is public, meaning that various groups of stakeholders are interested in submarine cables where each group has its own concern.

Public interest is most associated with being present in affairs traditionally belonging to stateoriented policy such as military affairs, international relations, state defence, et cetera. Legal scholars also find the public interest in problems of climate change; world cultural and natural heritage; high seas and its resources; the seabed of the oceans and their mineral resources; problems of biodiversity in areas beyond national jurisdiction; the Antarctic; protection of basic human rights; maintenance of international peace and security, et cetera. ${ }^{40}$ Apart from matters traditionally associated with strong role of a state and its governance, other fields of international relations where public interest may present appear. Gradually telecommunications also become to be considered as an area of public interest being essential source of connectedness. ${ }^{41}$ Therefore, it might be argued that the public interest is present in the legal regime of submarine cables given that submarine cables and their infrastructure serve for the interests of many stakeholders taken each separately and simultaneously for all them together.

The public interest is often associated with concerns of states as it follows from the traditional concept mentioned above. However, states and other international community's interests are not always equal, and what is considered by the state as a public interest does not always interpret by society equally. For instance, military affairs are widely considered as being a matter of a public matter. At the same time, state's population does not necessarily support acts of war or aggression covered by the concept of defense or protectionof national interests supported by the state. Public

38 B. Simma, 'From Bilateralism to Community Interest in International Law', Recueil des Cours de l'Academie de Droit International, 250, 1994, 217-384, at 234 [doi: 10.1093/acprof:oso/9780199588817.003.0067].

39 E. Kornicker Uhlmann, 'State Community Interests, Jus Cogens and Protection of the Global Environment: Developing Criteria for Peremptory Norms', Georgetown Environmental Law Review, 101, 1998-1999, 101-135, at 107.

40 Supra n. 31, at 156.

41 Supra n. 6, at 25. 
interest is the interest recognized by state and ensured by law, providing for interests of the whole community, the satisfaction of which serves as a condition and a guarantee of this community's existence and development. ${ }^{42} \mathrm{~A}$ particular attention in this definition one should turn to the aspect that interests of society and the state are not equal, but the special role of the state in the expression and protection of both interests is emphasized.

In the case of submarine cables, it appears to be the opposite. Both a state and a civil society as well as business representatives and other stakeholders support maintenance of existing cables and laying of new ones. This model works because both parties have their benefit from cables and understand their significance for each of them. States find submarine cables helpful in providing and ensuring their economic, security and other interests while civil society along with business sector finds their benefits in submarine cables in the opportunity to be connected and have a chance to communicate with the rest of the world.

In the framework of submarine cables as a public interest there is a recognized universal value of submarine cables associated with interests of international community. In this case, it is an interest serving for everyone's wealth and might be considered as a global public interest.

\section{(D) CONCLUSION}

Submarine cables constitute an interesting and to a certain extent unique object of legal regulation that unfortunately, sometimes left out of scope of international agenda and academic discussions. Certain distinguishing characteristics inherent to submarine cables such as accumulation of interests of several stakeholders, serving as critical and irreplaceable infrastructure and constituting a global public interest formulate multifaceted and multi-levelled legal regime of submarine cables nowadays. The legal regulation of submarine cables is represented by international agreements with leading role of the UNCLOS in place; domestic law of states enacted in the framework of implementation of international law norms; and concluded by private international law norms governing a great part of relations between stakeholders in the course of submarine cables projects. The current legal regime of submarine cables would not be possible to form without these distinguishing characteristics analysed in the present article and constituting submarine cables as an object of regulation under international law.

42 A. Chardantsev, Theory of State and Law: textbook for high schools (Yrait-M, Moscow, 2001), at 171. 